CASSOWARY volume 3 (2): 127 - 140

ISSN : 2614-8900

E-ISSN : 2622-6545

CProgram Pascasarjana Universitas Papua, https://pasca.unipa.ac.id/

\title{
Perilaku Masyarakat dalam Mengelola Sampah Rumah Tangga di Distrik Manokwari Timur Kabupaten Manokwari
}

\author{
Yosmina Waliki ${ }^{1^{*}}$, Ihwan Tjolli ${ }^{1}$, Hugo Warami ${ }^{1}$ \\ ${ }^{1}$ Program Studi S2 Ilmu Lingkungan Program, Pascasarjana Unipa, Jalan Gunung Salju \\ Amban, Manokwari - Indonesia 98314 \\ *Email: ocha.waliki86@gmail.com
}

\begin{abstract}
This study aims to (1) determine the behavior of the community in managing household waste in Manokwari Timur District, Manokwari Regency, (2) to analyze the factors that influence people's behavior in managing household waste. This research was conducted in Manokwari Regency, West Papua Province. The research method used is descriptive quantitative with data analysis using multiple regression analysis. The results showed: (1) The overall behavior of the community in managing household waste in East Manokwari District (65.5\%) was in the sufficiently supportive category. Meanwhile, as many as $34.9 \%$ are in the unsupported category, (2) The results of multiple linear regression analysis show that the variables of Formal Education, Guidance of Community Leaders, Infrastructure and Knowledge together have an effect on Community Behavior in Household Waste Management. The results of the partial relationship test show that the variables of formal education have a very significant effect on community behavior in household waste management; The variable of direction of community leaders has a significant effect on community behavior in managing household waste; infrastructure and knowledge variables did not affect people's behavior in household waste management.
\end{abstract}

Keywords: Knowledge, Rubbish Management, Formal Education, Community Leaders

ABSTRAK: Penelitian ini bertujuan untuk (1) mengetahui perilaku masyarakat dalam mengelola sampah rumah tangga di Distrik Manokwari Timur Kabupaten Manokwari, (2) menganalisa faktor yang mempengaruhi perilaku masyarakat dalam mengelola sampah rumah tangga. Penelitian ini dilaksanakan di Kabupaten Manokwari Pripinsi Papua Barat. Metode penelitian yang digunakan adalah deskriptif kuantitatif dengan analisis data secara analisis regresi berganda. Hasil penelitian menunjukkan: (1) Perilaku masyarakat secara keseluruhan dalam pengelolaan sampah rumah tangga di Distrik Manokwari Timur sebagian besar $(65.5 \%)$ berada pada kategori cukup menunjang. Sedangkan sebanyak $34.9 \%$ berada pada kategori tidak menunjang, (2) Hasil analisis regresi linier berganda, menunjukkan bahwa variabel Pendidikan Formal, Arahan Tokoh Masyarakat, Sarana Prasarana dan Pengetahuan secara bersama-sama berpengaruh terhadap Perilaku Masyarakat dalam Pengelolaan Sampah Rumah Tangga. Hasil pengujian hubungan parsial menunjukkan variabel pendidikan formal berpengaruh sangat nyata terhadap perilaku masyarakat dalam pengelolaan sampah rumah tangga; Variabel Arahan Tokoh Masyarakat berpengaruh nyata terhadap perilaku masyarakat dalam pengelolaan sampah rumah tangga; variabel sarana prasarana dan variabel pengetahuan 
tidak berpengaruh terhadap perilaku masyarakat dalam pengelolaan sampah rumah tangga.

Kata Kunci: Pengetahuan, Pengelolaan Sampah, Pendidikan Formal, Tokoh Masyarakat

\section{PENDAHULUAN}

Sampah rumah tangga, berdasarkan UU No. 18 Tahun 2008, sampah berasal dari kegiatan sehari-hari dalam rumah tangga yang tidak termasuk tinja dan sampah spesifik. Peraturan perundang-undangan tersebut juga menyebutkan bahwa pengelolaan sampah dilakukan dengan cara pengurangan sampah dan penanganan sampah. Pengurangan sampah sebagaimana dimaksud meliputi kegiatan pembatasan tim bulan sampah, pemanfaatan kembali sampah, dan pendauran ulang sampah.

Azkha (2007) Sampah merupakan salah satu masalah lingkungan hidup yang sejak lama telah menjadi perhatian dunia dan perlu mendapat penanganan yang serius agar tidak menimbulkan dampak yang membahayakan. Semua orang tidak terlepas dari permasalahan sampah karena setiap orang menghasilkan sampah dari proses aktivitasnya. Meningkatnya volume sampah seiring dengan laju pertumbuhan penduduk, peningkatan teknologi, aktivitas sosial budaya dan pertumbuhan ekonomi masyarakat di suatu daerah.

Pengelolaan sampah permukiman memerlukan partisipasi aktif individu dan kelompok masyarakat agar peran pemerintah tidak semakin berat. Meningkatkan partisipasi masyarakat dalam pengelolaan sampah, dapat dilaksanakan dengan melibatkan masyarakat sebagai penghasil sampah terbesar, dengan membudayakan perilaku pengelolaan sampah semenjak dini dari rumah tangga, sebagai struktur terendah dalam pengelolaan sampah perkotaan (Nurdin, 2004).
Partisipasi masyarakat dalam pengelolaan sampah merupakan bentuk keterlibatan dan keikutsertaan masyarakat secara aktif dan sukarela dalam keseluruhan proses pengelolaan sampah. Perilaku sehat diharapkan dapat memelihara, meningkatkan kesehatan dan melindungi diri dari ancaman penyakit, sedangkan lingkungan sehat diharapkan dapat menciptakan lingkungan yang kondusif, bebas polusi, pemukiman yang sehat dan pengelolaan sampah yang sehat (Azkha, 2006).

Perilaku masyarakat yang kurang dalam melakukan tindakan mengelola sampah rumah tangga, sebagian masyarakat hanya membuang sampah dengan mengumpulkannya dan dibiarkan begitu saja, sehingga dapat menimbulkan dampak terhadap lingkungan tempat tinggal maupun sekitarnya. Akibat dari perilaku masyarakat yang kurang dalam pengelolaan sampah ini yaitu dapat mengakibatkan berbagai macam masalah terhadap lingkungan,

Distrik Manokwari Timur terletak di daerah pesisir yang dibuktikan dengan 5 dari 7 kelurahan/kampung berada di wilayah pesisir, dan sisanya berada di punggung bukit (BPS, 2019). Berdasarakan survei awal yang dilakukan penulis, Distrik Manokwari Timur masih terlihat timbulan sampah disekitar daerah pemukiman, pantai, sungai dan jalan raya. Khususnya di daerah daerah padat penduduk seperti kampung Arowi dan sekitarnya. Sedangkan fenomena lainnya adalah hampir sebagian masyarakat masih membuang sampah ke laut dikarenakan pemukiman masyarakat langsung menghadap ke laut. 
Berdasarkan latar belakang dan perumusan masalah diatas, maka yang menjadi tujuan penelitian ini adalah:

1. Mengetahui perilaku masyarakat dalam mengelola sampah rumah tangga di Distrik Manokwari Timur Kabupaten Manokwari.

2. Menganalisa Faktor yang mempengaruhi perilaku masyarakat dalam mengelola sampah rumah tangga di Distrik Manokwari Timur Kabupaten Manokwari.

\section{MATERI DAN METODE}

Perilaku adalah segenap manifestasi hayati individu dalam berinteraksi dengan lingkungan, mulai dari perilaku yang paling nampak sampai yang tidak tampak, dari yang dirasakan sampai paling yang tidak dirasakan (Okviana, 2015). Perilaku merupakan hasil daripada segala macam pengalaman serta interaksi manusia dengan lingkunganya yang terwujud dalam bentuk pengetahuan, sikap dan tindakan. Perilaku merupakan respon/reaksi seorang individu terhadap stimulus yang berasal dari luar maupun dari dalam dirinya (Notoatmojo, 2010). Sedangkan menurut Wawan dan Dewi (2011) Perilaku merupakan suatu tindakan yang dapat diamati dan mempunyai frekuensi spesifik, durasi dan tujuan baik disadari maupun tidak. Perilaku adalah kumpulan berbagai faktor yang saling berinteraksi.

Skiner (1938) dalam Notoatmodjo (2011) merumuskan bahwa perilaku merupakan respon atau reaksi seseorang terhadap stimulus (rangsangan dari luar). Pengertian ini dikenal dengan teori "SO-R" atau "Stimulus-Organisme-Respon".

\section{Faktor - Faktor yang Mempengaruhi Perilaku}

Menurut teori Lawrance Green, dkk (dalam Notoatmodjo, 2007) menyatakan bahwa perilaku manusia dipe- ngaruhi oleh dua faktor pokok, yaitu faktor perilaku (behaviorcauses) dan faktor diluar perilaku (non behaviour causes). Selanjutnya perilaku itu sendiri diten-tukan atau terbentuk dari 3 faktor yaitu faktor predisposisi (predisposing factors), yang mencakup pengetahuan, sikap, kepercayaan, keyakinan, nilainilai dan sebagainya.

a. Pengetahuan apabila penerimaan perilaku baru atau adopsi perilaku melalui proses yang didasari oleh pengetahuan, kesadaran dan sikap yang positif, maka perilaku tersebut akan bersifat langgeng (long lasting) daripada perilaku yang tidak didasari oleh pengetahuan. Pengetahuan atau kognitif merupakan domain yang sangat penting dalam membentuk tindakan seseorang dalam hal ini pengetahuan yang tercakup dalam domain kognitif mempunyai tingkatan (Notoatmodjo, 2007).

b. Sikap adalah suatu predisposisi (keadaan mudah terpengaruh) terhadap seseorang, ide atau obyek yang berisi komponen-komponen cognitive, affective dan behavior (Linggasari, 2008). Terdapat tiga komponen sikap, sehubungan dengan faktor-faktor lingkungan kerja, sebagai berikut:

1) Afeksi (affect) yang merupakan komponen emosional atau perasaan.

2) Kognisi adalah keyakinan evaluatif seseorang. Keyakinan- keyakinan evaluatif, dimanifestasi dalam bentuk impresi atau kesan baik atau buruk yang dimiliki seseorang terhadap objek atau orang tertentu.

3) Perilaku, yaitu sebuah sikap berhubungan dengan kecenderungan seseorang untuk bertindak terhadap seseorang atau hal tertentu dengan cara tertentu (Winardi, 2004). 


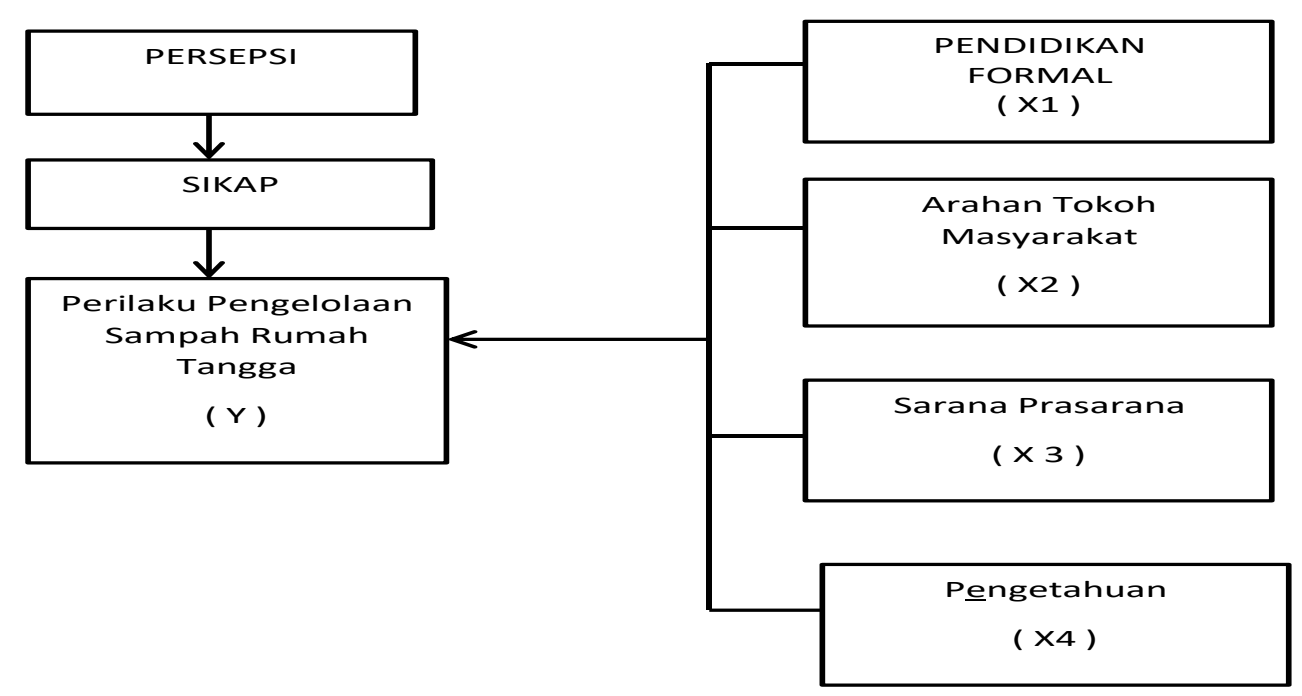

Gambar 1. Kerangka Pemikiran Penelitian

\section{Kerangka Pemikiran Penelitian}

Sikap seseorang berawal dan dipengaruhi oleh persepsi terhadap suatu obyek/persoalan. Persepsi akan mengarahkan seseorang untuk bersikap sesuai dengan apa yang dipahaminya/ dipersepsikan. Selanjutnya sikap akan mempengaruhi perilaku seseorang. Dalam penelitian ini berusaha melihat perilaku dan dikaitkan dengan faktorfaktor yang mempengaruhinya. Perilaku pengelolaan sampah rumah tangga di kalangan masyarakat, dibatasi dan dikaji dari beberapa faktor yang mempengaruhi perilaku, antara lain pendidikan formal, arahan tokoh masyarakat, sarana prsarana serta pengetahuan. Kerangka hubungan anta variabel dalam penelitian ini dapat dilihat pada Gambar 1.

\section{METODE PENELITIAN}

Penelitian ini dilakukan di wilayah Distrik Manokwari Timur Kabupaten Manokwari. Waktu pelaksanaan penelitian ini dilakukan selama \pm 2 bulan (Januari - Februari) Tahun 2020.

Populasi dalam penelitian ini adalah masyarakat yang tercatat sebagai penduduk wilayah Distrik Manokwari Timur.
Untuk menentukan sampel wilayah yang mencakup wilayah penelitian di Distrik Manokwari Timur yaitu dilakukan menggunakan teknik purposive sampling, dimana setiap populasi memiliki kemungkinan yang sama untuk dijadikan sampel (Sugiyono, 2009).

Dalam penelitian ini, peneliti memilih teknik pengambilan sampel acak atau random sampling/probability sampling. Dimana teknik dan sampel yang peneliti gunakan secara acak, tanpa memandang sampel atas dasar strata atau status sosial dari segi apapun. Maka Populasi ditentukan berdasarkan jumlah kepala keluarga sebanyak 1,730 KK, sedangkan penentuan jumlah sampel penelitian akan menggunakan rumus Slovin (Kusmayadi dan Endar, 2000).

Berdasarkan rumus slovin tersebut dengan tingkat kesalahan 15\% maka diperoleh jumlah sampel sebanyak 43 KK. Sugiyono (2007), untuk menentukan besarnya sampel pada setiap kelas dilakukan dengan alokasi proporsional agar sampel yang diambil lebih proporsional dilakukan dengan menggunakan perhitungan: 


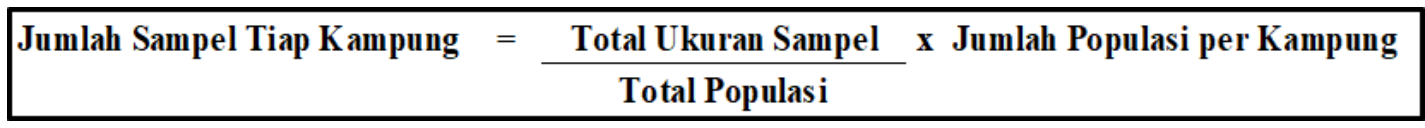

Tabel 1. Rincian Jumlah KK per Wilayah Penelitian

\begin{tabular}{|c|c|c|}
\hline No & Wilayah Penelitian (kelurahan) & Jumlah KK \\
\hline 1 & Pasir Putih & 791 \\
\hline 2 & Arowi & 544 \\
\hline 3 & Bakaro & 111 \\
\hline 4 & Aipiri & 79 \\
\hline 5 & Susweni & 131 \\
\hline & Total & 1.656 \\
\hline
\end{tabular}

Sumber Proyeksi Penduduk Indonesia 2010 - 2035 (BPS, 2019)

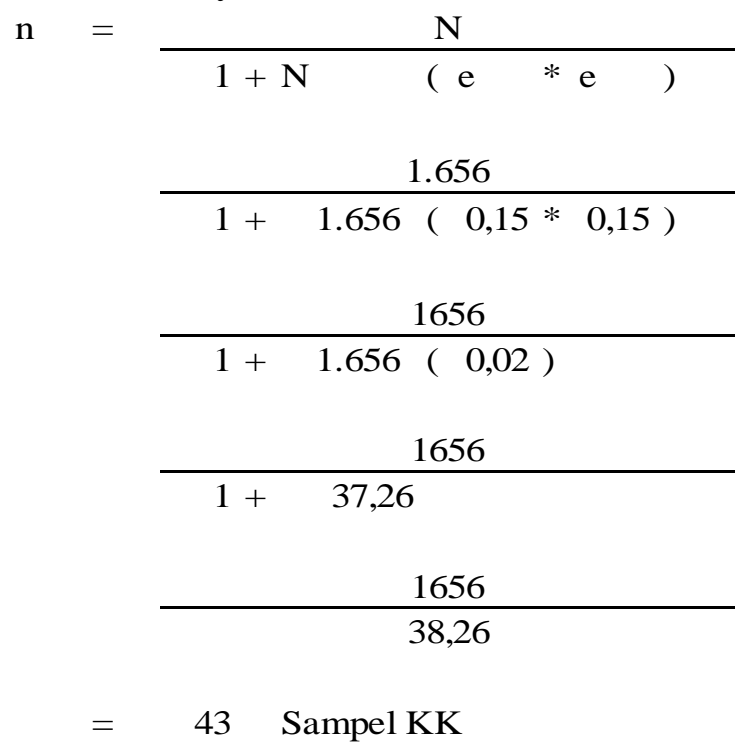

Tabel 2. Proposi sampel KK per wilayah penelitian

\begin{tabular}{llccc}
\hline No & \multicolumn{1}{c}{$\begin{array}{c}\text { Wilayah Penelitian } \\
\text { (kelurahan) }\end{array}$} & Jumlah KK & Perhitungan & $\begin{array}{c}\text { Jumlah } \\
\text { Sampel KK }\end{array}$ \\
\hline 1 & Pasir Putih & 791 & $(43 / 1,656) \times 791$ & 21 \\
2 & Arowi & 544 & $(43 / 1,656) \times 544$ & 14 \\
3 & Bakaro & 111 & $(43 / 1,656) \times 111$ & 3 \\
4 & Aipiri & 79 & $(43 / 1,656) \times 79$ & 2 \\
5 & Susweni & 131 & $(43 / 1,656) \times 131$ & 3 \\
\hline & Total & 1.656 & & 43 \\
\hline
\end{tabular}

Sumber: Perhitungan berdasarkan Sugiyono (2007)

\section{Sumber Data}

Data yang digunakan dalam penelitian ini menggunakan data primer dan data sekunder. Data primer dalam penelitian ini berupa karakteristik responden, perilaku responden, faktor internal yang terdiri dari 4 (empat) indikator yaitu pengetahuan, tingkat pendidikan, pendapatan masyarakat dan waktu luang dan faktor eksternal yang terdiri dari 3 (tiga) indikator yaitu sarana dan prasarana, penegakkan hukum dan sosialisasi dalam pengelolaan sampah serta faktor pendorong partisipasi dalam 
pengelolaan sampah, dan di dukung hasil wawancara terstruktur langsung dari informan.

Data sekunder dalam penelitian meliputi gambaran geografi dan data kependudukan di Distrik Manokwari Timur, data dari instansi terkait Dinas Lingkungan Hidup Kabupaten Manokwari, situs internet, gambaran geografi, literatur, jurnal-jurnal, skripsi, dan tesis serta laporan penelitian yang ada kaitannya dengan penelitian ini.

\section{Definisi Operasional Variabel}

Menurut Sugiyono (2013) mendefinisikan bahwa yang dimaksud dengan variabel adalah suatu atribut atau sifat atau nilai dari orang, objek atau kegiatan yang mempunyai variasi tertentu yang ditetapkan oleh peneliti untuk dipelajari dan ditarik kesimpulannya. Variabel yang digunakan dalam penelitian ini adalah variabel independen (X) dan variabel dependen $(\mathrm{Y})$. Adapun penjelasannya sebagai berikut:

\section{Perilaku (Y)}

Perilaku masyarakat diukur berdasarkan jumlah skor dari pernyataan pada kuesioner dengan menggunakan skala likert aban yang tegas terhadap suatu permasalahan yang dinyatakan. Azwar (200dan setiap pernyataan memiliki skor jaw8), pengukuran perilaku yang berisi pernyataan-pernyataan terpilih digunakan untuk mengungkapkan perilaku responden. Kriteria pengukuran perilaku dapat dilihat pada Tabel 3.

Selanjutnya total nilai skor dari seluruh item pernyataan dijumlahkan kemudian dikelompokkan dalam tiga kategori berdasarkan jumlah selang skor, yaitu (1) Perilaku yang sangat menunjang pengelolaan sampah yang baik; (2) Perilaku yang cukup menunjang pengelolaan sampah yang baik; (3) Perila$\mathrm{ku}$ yang tidak menunjang pengelolaan sampah yang baik. Pengukuran perilaku dapat dilihat pada Tabel 3.

Tabel 3. Pengukuran Perilaku Responden

\begin{tabular}{clc}
\hline No. & \multicolumn{1}{c}{ Pernyataan } & \multicolumn{1}{c}{ Tanggapan } \\
\cline { 2 - 3 } & & \multicolumn{1}{c}{$\mathbf{2}$} \\
\hline 1. & $\begin{array}{l}\text { Sampah yang dihasilkan harus dibuang pada tempatnya } \\
\text { Sampah yang dihasilkan harus dapat dikelola dengan baik agar } \\
\text { tidak menumpuk }\end{array}$ \\
3 & $\begin{array}{l}\text { Pemisahan sampah basah dan sampah kering sangat di perlukan } \\
\text { Pemisahan sampah basah dan sampah kering sangat membantu } \\
\text { dalam mengelola sampah lebih lanjut }\end{array}$ \\
5 & $\begin{array}{l}\text { Pengelolaan sampah basah/kering dapat dilakukan dengan cara } \\
\text { menimbun }\end{array}$ \\
6 & $\begin{array}{l}\text { Pengelolaan sampah basah/kering dapat dilakukan dengan cara } \\
\text { membakar }\end{array}$ \\
7 & $\begin{array}{l}\text { Sampah yang dihasilkan harus diangkut ke tempat pembuangan } \\
\text { sementara agar tidak menumpuk di lingkungan sekitar rumah }\end{array}$ \\
8 & $\begin{array}{l}\text { Membuang sampah di tempat penampungan sementara dapat } \\
\text { menghindari penimbunan sampah di rumah }\end{array}$ \\
9 & $\begin{array}{l}\text { Mengangkut sampah ke tempat pembuangan sementara } \\
\text { sebaiknya dilakukan setiap hari }\end{array}$ \\
10 & $\begin{array}{l}\text { Kita seharusnya menegur orang yang hendak membuang } \\
\text { sampah bukan pada tempatnya }\end{array}$ \\
\hline
\end{tabular}

Sumber: Data Sekunder 
Tabel 4. Kriteria, Indikator dan Interval Perilaku Masyarakat

\begin{tabular}{cc}
\hline Kriteria & Interval Skor \\
\hline Perilaku sangat menunjang & $24-30$ \\
Perilaku Cukup menunjang & $17-23$ \\
Perilaku tidak menunjang & $10-16$ \\
\hline
\end{tabular}

\section{Method of Succesive Interval (MSI)}

Bebarapa data ordinal diubah menjadi data interval melalui Method of Succesive Interval (MSI). Setelah data terkumpul, beberapa data skala ordinal terlebih dahulu dilakukan perubahan data ke dalam skala interval. Metode yang digunakan dalam proses transformasi data dari skala ordinal ke skala interval menggunakan Method of Successive Interval. Tahapan-tahapan $\mathrm{Me}$ thod of Succesive Interval (MSI) adalah sebagai berikut:

1. Menentukan frekuensi setiap respon (fi)

2. Menentukan proporsi setiap respon dengan membagi frekuensi dengan jumlah sampel, dengan rumus:

$$
\mathrm{pi}=\frac{f i}{n}
$$

Rumus menghitung NS:
Dimana: pi $=$ proporsi $;$ fi $=$ frekuensi $; \mathrm{n}=$ jumlah responden

3. Menjumlahkan proporsi secara berurutan untuk setiap respon sehingga diperoleh proporsi kumulatif, dengan rumus: $\mathrm{Pki}=\mathrm{pi}-1+\mathrm{p}$

4. Menentukan nilai $\mathrm{Z}$ untuk masingmasing proporsi kumulatif yang dianggap menyebar mengikuti sebaran normal baku.

5. Menghitung Nilai Skala (NS) untuk masing-masing respon dengan rumus menghitung NS.

6. Merubah Nilai Skala (NS) terkecil menjadi sama dengan satu (1) dan mentransformasikan masing-masing skala menurut perubahan skala terkecil sehingga diperoleh nilai skala transformasi (Y).

\section{Density at Lower limit - Density at Upper limit}

$\mathrm{NS}=$

$$
\text { Area at Under upper limit - Area at Under lower limit }
$$

Dimana:

Density at Lower Limit = Densitas Batas Bawah

Density at Upper Limit = Densitas Batas Atas

Area at Under Upper Limit = Proporsi Kumulatif untuk pilihan jawaban yang dicari

Area at Under Lower Limit = Proporsi Kumulatif untuk pilihan jawaban yang sebelumnya 


\section{Analisis Regresi Linier Berganda}

Untuk mengetahui besarnya pengaruh faktor predisposisi (predisposing factors) yaitu pengetahuan, sikap; faktor pemungkin (enabling factor) yaitu sarana dan prasarana, sosialisasi atau pelatihan; faktor penguat (reinforcement factor) yaitu undang-undang, peraturanperaturan, pengawasan mempengaruhi perilaku masyarakat digunakan analisis Regresi Linier Berganda (linier multiple regression) pada program SPSS versi 21 , dengan persamaan sebagai berikut (Supranto, 1995):

\begin{tabular}{|c|c|}
\hline \multicolumn{2}{|c|}{$\begin{array}{l}\mathbf{Y}=\mathbf{b} \mathbf{0}+\mathbf{b} \mathbf{1 X} \mathbf{1}+\mathbf{b} \mathbf{2} \mathbf{X} \mathbf{2}+\mathbf{b} \mathbf{3} \mathbf{X} 3+\ldots . .+\mathbf{b}_{\mathbf{n}} \mathbf{X}_{\mathbf{n}} \\
\text { Keterangan : }\end{array}$} \\
\hline$Y=$ & $\begin{array}{lcc}\text { Perilaku } & \text { Masyarakat } & \text { dalam } \\
\text { mengelola } & \text { sampah } & \text { rumah } \\
\text { tangga } & & \end{array}$ \\
\hline $\mathrm{b}_{0}=$ & $\begin{array}{l}\text { Harga Y ketika harga } \mathrm{X}=0 \\
\text { (harga konstan) }\end{array}$ \\
\hline$b_{1-6}=$ & Koefisien regresi \\
\hline $\mathrm{X}_{1}=$ & Pendidikan Formal \\
\hline $\mathrm{X}_{2}=$ & Arahan Tokoh Masyarakat \\
\hline $\mathrm{X}_{3}=$ & Sarana Prasarana \\
\hline $\mathrm{X}_{4}=$ & Pengetahuan \\
\hline
\end{tabular}

\section{HASIL DAN PEMBAHASAN} Karakteristik Responden

Responden dalam penelitian ini adalah penduduk di kawasan pesisir Distrik Manokwari Timur yang meliputi beberapa kampung yaitu Mansinam,
Pasir Putih, Arowi, Bakaro, Aipiri, Susweni. Data mengenai responden yang dikumpulkan melalui kuesioner maupun berbagai data sekunder yang bersumber langsung dari berbagai pihak dan instansi yang terkait dengan penelitian ini.

\section{Tingkat Pendidikan}

Responden dalam penelitian ini adalah masyarakat yang bedomisili di Distrik Manokwari Timur yaitu distrik Manokwari Timur yang meliputi wilayah kampung-kampung meliputi Mansinam, Pasir Putih, Arowi, Bakaro, Aipiri, dan Susweni. Sebaran jenjang pendidikan terakhir responden dibagi menjadi 3 kelompok yaitu tingkat SD, SMPSMA, serta Perguruan Tinggi seperti yang terlihat pada Tabel 5 .

Berdasarkan Tabel 5. tingkat pendi-dikan formal responden yang dijadikan sampel menunjukkan bahwa sebagian besar responden memiliki jenjang pen-didikan SMA dan SMP yaitu sebesar $65 \%$. Di samping itu jumlah responden yang memiliki pendidikan jenjang Strata 1 (sarjana) relatif banyak yaitu 30 persen. Hal ini mengindikasikan bahwa responden dapat dikatakan sudah relatip terpelajar, sehingga dalam proses wa-wancara dan mengemukakan pendapat relatip lancar. Demikian juga cukup baik dalam mengeluarkan pendapat pada saat wawancara.

Tabel 5. Tingkat Pendidikan responden

\begin{tabular}{clcc}
\hline No. & Jenjang Pendidikan & Jumlah & Persen $(\%)$ \\
\hline 1. & SD & 2 & 5 \\
2. & SMP-SMA & 28 & 65 \\
3. & Sarjana & 13 & 30 \\
\hline & & 43 & 100 \\
\hline
\end{tabular}

Sumber: Hasil Pengolahan Data Primer 
Tabel 6. Sebaran Responden Berdasarkan Umur

\begin{tabular}{cccc}
\hline No. & Usia $($ Thn $)$ & Jumlah & Persen(\%) \\
\hline 1. & 20 - 30 Tahun & 32 & 32 \\
2. & 31 - 40 Tahun & 12 & 27 \\
3. & 41 - 50 Tahun & 7 & 16 \\
4. & $51-60$ Tahun & 6 & 14 \\
5. & 61 - 71 Tahun & 4 & 9 \\
\hline
\end{tabular}

Sumber: Hasil Pengolahan Data Primer

Tabel 7. Perilaku Masyarakat dalam Mengelola Sampah Rumah Tangga di Distrik Manokwari Timur Kabupaten Manokwari

\begin{tabular}{|c|c|c|c|c|c|c|c|}
\hline \multirow[t]{2}{*}{ No. } & \multirow[t]{2}{*}{ Pernyataan } & \multicolumn{2}{|c|}{$\begin{array}{l}\text { SANGAT } \\
\text { Menunjang }\end{array}$} & \multicolumn{2}{|c|}{$\begin{array}{c}\text { Cukup } \\
\text { Menunjang }\end{array}$} & \multicolumn{2}{|c|}{$\begin{array}{c}\text { Tidak } \\
\text { menunjang }\end{array}$} \\
\hline & & $\mathrm{Jml}$ & $\%$ & $\mathrm{Jml}$ & $\%$ & Jml & $\%$ \\
\hline 1. & $\begin{array}{l}\text { Sampah yang dihasilkan harus dibuang } \\
\text { pada tempatnya }\end{array}$ & 0 & 0 & 25 & 51.8 & 18 & 41.9 \\
\hline 2 & $\begin{array}{l}\text { Sampah yang dihasilkan harus dapat } \\
\text { dikelola dengan baik agar tidak menumpuk }\end{array}$ & 4 & 9.3 & 27 & 62.8 & 12 & 27.9 \\
\hline 3 & $\begin{array}{l}\text { Pemisahan sampah basah dan sampah } \\
\text { kering sangat di perlukan }\end{array}$ & 3 & 7.0 & 23 & 53.5 & 17 & 39.5 \\
\hline 4 & $\begin{array}{l}\text { Pemisahan sampah basah dan sampah } \\
\text { kering sangat membantu dalam mengelola } \\
\text { sampah lebih lanjut }\end{array}$ & 2 & 4.7 & 34 & 79.1 & 7 & 16.3 \\
\hline 5 & $\begin{array}{l}\text { Pengelolaan sampah basah/kering dapat } \\
\text { dilakukan dengan cara menimbun }\end{array}$ & 4 & 9.3 & 31 & 72.1 & 8 & 18.6 \\
\hline 6 & $\begin{array}{l}\text { Pengelolaan sampah basah/kering dapat } \\
\text { dilakukan dengan cara membakar }\end{array}$ & 1 & 2.3 & 31 & 72.1 & 11 & 25.6 \\
\hline 7 & $\begin{array}{l}\text { Sampah yang dihasilkan harus diangkut ke } \\
\text { tempat pembuangan sementara agar tidak } \\
\text { menumpuk di lingkungan sekitar rumah }\end{array}$ & 3 & 7.0 & 25 & 58.1 & 15 & 34.9 \\
\hline 8 & $\begin{array}{l}\text { Membuang sampah di tempat } \\
\text { penampungan sementara dapat menghindari } \\
\text { penimbunan sampah di rumah }\end{array}$ & 2 & 4.7 & 30 & 69.8 & 11 & 25.6 \\
\hline 9 & $\begin{array}{l}\text { Mengangkut sampah ke tempat } \\
\text { pembuangan sementara sebaiknya } \\
\text { dilakukan setiap hari }\end{array}$ & 2 & 4.7 & 27 & 62.8 & 14 & 32.6 \\
\hline 10 & $\begin{array}{l}\text { Kita seharusnya menegur orang yang } \\
\text { hendak membuang sampah bukan pada } \\
\text { tempatnya }\end{array}$ & 1 & 2.3 & 28 & 65.1 & 14 & 32.6 \\
\hline \multicolumn{2}{|c|}{ Perilaku Masyarakat } & 2 & 4.7 & 26 & 60.5 & 15 & 34.9 \\
\hline
\end{tabular}

Sumber : Hasil Pengolahan Data Primer

\section{Umur}

Usia adalah umur seseorang yang dihitung dari sejak lahir, yang berpengaruh secara langsung terhadap kemampuan fisik, pola berpikir, dan bertindak seseorang. Sebaran responden berdasarkan usia pada penelitian ini terlihat pada Tabel 6 .
Pada Tabel 6. terlihat bahwa sebaran usia responden terbanyak pada usia antara 20 - 30 tahun yaitu sebanyak $32 \%$ dan pada usia antara 31 - 40 tahun sebanyak $27 \%$. Hal tersebut menunjukkan bahwa sebaran usia responden berada pada usia produktif, dimana pada usia tersebut umumnya masih aktif 
bekerja dan beraktifitas. Perilaku Masyarakat daalam Pengelolaan Sampah Rumah Tangga.

Data pada Tabel 7 menunjukkan bahwa pe-rilaku masyarakat secara keseluruhan dalam pengelolaan sampah rumah tang-ga di Distrik Manokwari Timur sebagian besar 65.5 persen berada pada kategori cukup menunjang. Sedangkan sebanyak 34.9 persen berada pada kategori tidak menunjang. Demikian juga halnya pada item-item perilaku lainnya, semua bera-da pada kategori cukup menunjang.

Berbagai faktor yang mempengaruhi perilaku masyarakat tersebut, diantaranya umumnya responden adalah kelompok terpelajar dam sudah paham betul dengan pengelolaan sampah rumah tangga.

\section{Analisis Faktor-Faktor yang Mempe- ngaruhi Perilaku Pengelolaan Sampah Rumah Tangga}

Berdasarkan pengolahan data primer, maka untuk mengetahui pengaruh Pendidikan formal (X1), Arahan Tokoh Masyarakat (X2), Sarana Prasarana (X3), Pengetahuan (X4), terhadap Perilaku Pengelolaan Sampah (Y) maka diperoleh koefisien regresi linier berganda antara variabel bebas dengan variabel terikat disajikan pada Tabel 8 .
Hasil analisis regresi linear berganda untuk tingkat partisipasi masyarakat dalam mengelola sampah rumah tangga, diperoleh model persamaan sebagai berikut:

$$
\begin{aligned}
& \mathbf{Y}=2.797+1.046 \mathbf{X}_{1}+0.489 \mathbf{X}_{2}+ \\
& 0.317 \mathbf{X}_{3}+0.471 \mathbf{X}_{\mathbf{4}}
\end{aligned}
$$

Dimana :

$$
\begin{array}{ll}
\mathrm{Y} & =\text { Tingkat Perilaku Masyarakat } \\
\mathrm{a} & =\text { Konstanta } \\
\beta_{1}-\beta 3 & =\text { Koefisien Regresi } \\
\mathrm{X}_{1} & =\text { Pendidikam } \\
\mathrm{X}_{2} & =\text { Arahan Tokoh Masyarakat } \\
\mathrm{X}_{3} & =\text { Sarana Prasarana } \\
\mathrm{X}_{4} & =\text { Pengetahuan } \\
\mathrm{e} & =\text { Faktor Galat }
\end{array}
$$

Hasil perhitungan analisis korelasi diketahui bahwa korelasi antara variabel $\mathrm{X}_{1}$ sampai dengan $\mathrm{X}_{4}$ dengan variabel $\mathrm{Y}$ adalah sebesar 0.762. Hal ini menjelaskan bahwa Perilaku Masyarakat dalam pengelolaan Sampah di kabupaten Manokwari dipengaruhi oleh keempat karakteristik responden sebesar $76.2 \%$, dan sisanya sebesar $23.8 \%$ dipengaruhi oleh faktor lainnya di luar model. Menurut Sarwono (2006) koefisien korelasi sebesar 0.762 menunjukkan bahwa korelasi variabel X1 - X4 secara bersamaan dengan variabel $\mathrm{Y}$ termasuk dalam korelasi kuat.

Tabel 8. Koefisien Regresi Linier Berganda Antara Variabel Bebas Dengan Variabel Terikat

\begin{tabular}{lcc}
\hline \multicolumn{1}{c}{ Variabel } & Koefisien Regresi & t hitung \\
\hline Pendidikan $\left(\mathrm{X}_{1}\right)$ & 1.046 & $4.249^{* *}$ \\
\hline Arahan Tokoh Masyarakat $\left(\mathrm{X}_{2}\right)$ & 0.489 & $2.557^{*}$ \\
\hline Sarana Produksi $\left(\mathrm{X}_{3}\right)$ & 0.317 & 1.494 \\
\hline Pengetahuan $\left(\mathrm{X}_{4}\right)$ & 0.471 & 1.816 \\
\hline Constant $=2.797$ & \\
Koef. Determinasi $\left(\mathrm{R}^{2}\right)=0.762$, Koef. Korelasi $(\mathrm{R})=0.873$ & \\
$\mathrm{t}$ Tabel $(0,05)=2.02, \mathrm{t}$ Tabel $(0,01)=2.71$ & \\
\hline Keterangan : & \\
$* \quad=$ signifikan pada tingkat kepercayaan $95 \%$ & \\
$* * \quad=$ Sangat signifikan pada tingkat kepercayaan $99 \%$ &
\end{tabular}


Hasil analisis regresi memperlihatkan bahwa hubungan positif antara perilaku Masyarakat (Y) terjadi dengan faktor pendidikan (X1), Arahan Tokoh Masyarakat (X2), Sarana Prasarana (X3) dan Pengetahuan (X4).

\section{Pengaruh Secara Simultan}

Untuk menguji tingkat keberartian pengaruh variabel bebas secara bersamasama (simultan) terhadap perilaku pengelolaan sampah, dapat dilihat pada analisis varians atau uji statistik $F$. Analisis varians uji $\mathrm{F}$ disajikan pada Tabel 9.

Berdasarkan hasil analisis varians uji statistik $F$, diketahui $F$ hitung (30.374) lebih besar daripada $F$ Tabel $(0.05 ; 4.38)=2.62$. Semua variabel bebas, yang terdiri dari pendidikan (X1), Arahan Tokoh Masyarakat (X2), Sarana Prasarana (X3) dan Pengetahuan (X4).
Hal ini mengandung pengertian bahwa apabila variabel bebas tersebut ditambah atau dikurangi.dapat meningkatkan atau menurunkan partisipasi pengunjung dalam hal kebersihan rumah sakit.

\section{Pengaruh Secara Parsial}

Secara parsial pengaruh masingmasing variabel ditunjukkan oleh uji t, seperti pada Tabel 10.

Berdasarkan Tabel 10. hasil uji $\mathrm{t}$ memberikan gambaran bahwa variabel tingkat pendidikan formal berpengaruh sangat nyata terhadap perilaku masyarakat dalam mengelola sampah rumah tangga; variabel arahan tokoh masyarakat berpengaruh nyata terhadap perilaku masyarakat; serta variabel sarana prasarana dan pengetahuan tidak berpengaruh nyata terhadap perilaku masyarakat dalam pengelolaan sampah rumah tangga.

Tabel 9. Analisis Varians Uji F

\begin{tabular}{ccccc}
\hline Sumber variasi & Jumlah Kuadrat & Derajat Bebas & $\begin{array}{c}\text { Kuadrat } \\
\text { rata-rata }\end{array}$ & F \\
\hline Regresi & 108.276 & 4 & 27.069 & 30.374 \\
Residual & 33.865 & 38 & .891 & \\
Total & 142.140 & 42 & & \\
\hline
\end{tabular}

Sumber : Hasil Pengolahan Data Primer

Tabel 10. Hubungan Parsial Variabel Bebas Terhadap Variabel Terikat

\begin{tabular}{cccccc}
\hline \multirow{2}{*}{ variabel } & \multirow{2}{*}{ t hitung } & \multicolumn{2}{c}{ t table } & \multirow{2}{*}{ Peluang } & \multirow{2}{*}{ Keterangan } \\
\cline { 3 - 4 } & & $\boldsymbol{\alpha ~ 0 , 0 5}$ & $\boldsymbol{\alpha ~ 0 , 0 1}$ & & \\
\hline $\mathrm{X}_{1}$ & 4.249 & 2.024 & 2.71 & .0000 & Sangat Signifikan \\
\hline $\mathrm{X}_{2}$ & 2.557 & 2.021 & 2.704 & 0.015 & Signifikan \\
$\mathrm{X}_{3}$ & 1.494 & 2.021 & 2.704 & 0.144 & Tidak Signifikan \\
$\mathrm{X}_{4}$ & 1.816 & 2.021 & 2.704 & 0.077 & Tidak Signifikan \\
\hline
\end{tabular}

Sumber: Hasil Pengolahan Data Primer 


\section{Pengaruh Pendidikan Formal terhadap Perilaku Masyarakat dalam Pengelolaan Sampah Rumah Tangga}

Berdasarkan hasil pengujian statistik, nilai t hitung (4.249) lebih besar daripada t Tabel $(0.01 ; 4.33)=2,024$. Hal ini berarti bahwa pendidikan formal berpengaruh sangat nyata terhadap perilaku masyarakat dalam mengelola sampah rumah tangga. Dengan tingkat pendidikan yang dimiliki akan berdampak pada pola pikir dan wawasan seseorang sehingga akan mengarahkan seseorang dalam mengambil keputusan, termasuk dalam perilaku pengelolaan sampah. Artinya semakin tinggi tingkat pendidikan seseorang maka semakin rasional dalam berpikir dan juga semakin baik dalam pengambilan keputusan.

Koefisien regresi yang bertanda positif menunjukkan bahwa tingkat pendidikan formal berpengaruh secara positip terhadap perilaku masyarakat dalam pengelolaan sampah rumah tangga. Hal ini mengandung pengertian bahwa semakin tinggi tingkat pendidikan formal, maka perilaku akan semakin menunjang pula pengelolaan sampah rumah tangga.

\section{Pengaruh Arahan Tokoh Masyarakat terhadap Perilaku Masyarakat dalam Pengelolaan Sampah Rumah Tangga}

Berdasarkan hasil pengujian statistik nilai t hitung (2.557) lebih besar daripada t Tabel $(0.05 ; 4.33)=2,024$. Hal ini berarti bahwa arahan tokoh masyarakat atau tokoh agama berpengaruh nyata terhadap perilaku masyarakat dalam mengelola sampah rumah tangga. Dengan adanya arahan dari tokoh masyarakat akan memotivasi masyarakat dalam mengelola sampah rumah tangga dengan baik. Artinya, semakin sering arahan atau himbauan dari tokoh masyarakat tentang kebersihan lingkungan, maka semakin besar kemungkinan untuk mengikuti himbauan tersebut.

Koefisien regresi yang bertanda positif menunjukkan bahwa arahan tokoh masyarakat berpengaruh secara positip terhadap perilaku masyarakat dalam pengelolaan sampah rumah tangga. Hal ini mengandung pengertian bahwa semakin sering arahantokoh masyarakat, maka perilaku masyarakat akan semakin menunjang dalam pengelolaan sampah rumah tangga.

\section{Pengaruh Sarana Produksi terhadap Perilaku Masyarakat dalam Pengelo- laan Sampah Rumah Tangga}

Berdasarkan hasil pengujian statistik nilai t hitung (1.494) lebih kecil daripada t Tabel $(0.05 ; 4.33)=2,024$. Hal ini berarti bahwa variabel Sarana Produksi tidak berpengaruh nyata terhadap perilaku masyarakat dalam mengelola sampah rumah tangga. Dengan perkataan lain bahwa menunjang tidaknya perilaku masyarakat dalam pengelolaan sampah rumah tangga, bukan disebabkan oleh ketersediaan sarana produksi.

\section{Pengaruh Pengetahuan terhadap Perilaku Masyarakat dalam Penge- lolaan Sampah Rumah Tangga}

Berdasarkan hasil pengujian statistik nilai t hitung $(1.816)$ lebih kecil daripada t Tabel $(0.05 ; 4.33)=2,024$. Hal ini berarti bahwa variabel pengetahuan tidak berpengaruh terhadap perilaku masyarakat dalam pengelolaan sampah rumah tangga

\section{KESIMPULAN DAN SARAN}

\section{Kesimpulan}

1. Perilaku masyarakat secara keseluruhan dalam pengelolaan sampah rumah tangga di Distrik Manokwari Timur sebagian besar (65.5) persen 
berada pada kategori cukup menunjang. Sedangkan sebanyak 34.9 persen berada pada kategori tidak menunjang. Demikian juga halnya komponen jenis perilaku lainnya, semua menunjukkan berada pada kategori cukup menunjang.

2. Hasil analisis regresi linier berganda, menunjukkan bahwa variabel Pendidikan Formal (X1), Arahan Tokoh Masyarakat (X2), Sarana Prasarana (X3) dan Pengetahuan (X4) secara bersama-sama berpengaruh terhadap Perilaku Masyarakat dalam Pengelolaan Sampah Rumah Tangga (Y).. Hasil pengujian hubungan parsial menunjukkan variabel pendidikan formal (X1) berpengaruh sangat nyata terhadap perilaku masyarakat dalam pengelolaan sampah rumah tangga (Y); Variabel Arahan Tokoh Masyarakat (X2) berpengaruh nyata terhadap perilaku masyarakat dalam pengelolaan sampah rumah tangga (Y); variabel sarana prasarana (X3) dan variabel pengetahuan (X4) tidak berpengaruh terhadap perilaku masyarakat dalam pengelolaan sampah rumah tangga $(\mathrm{Y})$.

\section{Saran}

1. Untuk meningkatkan pengelolaan sampah rumah tangga dikalangan masyarakat secara baik, perlu adanya kegiatan edukasi secara berkesinambungan agar kesadaran dan partisipasi di kalangan masyarakat tetap terjaga.

2. Perlu adanya penelitian lanjutan yang terkait topic penelitian ini yang berusaha mengakomodir variabelvariabel yang belum dikaji di dalam penelitian ini.

\section{DAFTAR PUSTAKA}

Azkha. N. 2006. Analisis Timbulan, Komposisi Dan Karakteristik Sampah di Kota Padang. Jurnal Kesehatan Masyarakat. September 2006, I.

Azkha. N. 2007. Pemanfaatan Komposter Berskala Rumah Tangga. Jurnal Kesehatan Masyarakat. September 2007.

Azwar, Saifudin. 2003. Sikap Manusia, Teori dan Pengukurannya, Yogyakarta : Pustaka Pelajar

Badan Pusat Statistik. 2019. Kabupaten Manokwari Dalam Angka 2018. BPS

Kusmayadi dan Endar Sugiarto. 2000. Metodologi Penelitian dalam Bidang Kepariwisataan. Jakarta: PT.Gramedia Pustaka Utama.

Linggasari. 2008. Faktor-faktor yang mempengaruhi perilaku terhadap penggunaan alat pelindung diri (APD) di Departemen Engineering PT Indah KIAT PULP \& PAPER TBK Tangerang. Fakultas Kesehatan Masyarakat, Universitas Indonesia.

Nurdin Usman. 2004. Implementasi dalam Birokrasi Pembangunan. Bandung

Notoatmodjo Soekidjo. 2007. Promosi Kesehatan dan Ilmu Perilaku. Jakarta : Rineka Cipta

Notoatmodjo Soekidjo. 2010. Ilmu Perilaku Kesehatan. Jakarta: Rineka Cipta

Notoatmodjo Soekidjo. 2011. Kesehatan Masyarakat. Jakarta : Rineka Cipta 
Okviana. 2015. Analisis Pengaruh

Kualitas Pelayanan, Bauran Pemasaran Dan Religius Stimuli Terhadap Keputusan Memilih Jasa Perbankan (Studi Kasus Dosen dan Karyawan IAIN Salatiga). Ilmu Ekonomi,Politik, Sosial, Budaya dan Pertahanan Negera. Tesis

Sugiyono. 2007. Metode Penelitian Kuantitatif Kualitatif dan R\&D. Bandung: Alfabeta.

Sugiyono, 2009, Metode Penelitian Kuantitatif, Kualitatif dan R\&D, Bandung : Alfabeta.

Sugiyono. 2013. Metodelogi Penelitian Kuantitatif, Kualitatif Dan R\&D. Bandung: Alfabeta.

Supranto J. 1995. Ekonometrika Dasar. Edisi 2. Jakarta: Lembaga Penerbitan Fakultas. Ekonomi Universitas Indonesia

Undang-Undang Republik Indonesia Nomor 18 Tahun 2008 Tentang Pengelolaan Sampah.

Wawan, A., Dewi M. 2011. Teori dan Pengukuran Pengetahuan, Sikap, dan Perilaku Manusia. Yogyakarta: Nuha Medika 